\title{
Corrosion-Resistant High-Entropy Alloys: A Review
}

\author{
Yunzhu Shi ${ }^{1,3}$, Bin Yang ${ }^{2, *}$ and Peter K. Liaw ${ }^{3, *}$ \\ 1 State Key Laboratory for Advanced Metals and Materials, University of Science and Technology Beijing, \\ Beijing 100083, China; yshi26@163.com \\ 2 Collaborative Innovation Center of Steel Technology, University of Science and Technology Beijing, \\ Beijing 100083, China \\ 3 Materials Science \& Technology, The University of Tennessee, Knoxville, TN 37996, USA \\ * Correspondence: byang@ustb.edu.cn (B.Y.); pliaw@utk.edu (P.K.L.); \\ Tel.: +86-106-233-3351 (B.Y.); +1-865-974-6356 (P.K.L.)
}

Academic Editors: Michael C. Gao and Junwei Qiao

Received: 30 December 2016; Accepted: 2 February 2017; Published: 5 February 2017

\begin{abstract}
Corrosion destroys more than three percent of the world's gross domestic product. Therefore, the design of highly corrosion-resistant materials is urgently needed. By breaking the classical alloy-design philosophy, high-entropy alloys (HEAs) possess unique microstructures, which are solid solutions with random arrangements of multiple elements. The particular locally-disordered chemical environment is expected to lead to unique corrosion-resistant properties. In this review, the studies of the corrosion-resistant HEAs during the last decade are summarized. The corrosion-resistant properties of HEAs in various aqueous environments and the corrosion behavior of HEA coatings are presented. The effects of environments, alloying elements, and processing methods on the corrosion resistance are analyzed in detail. Furthermore, the possible directions of future work regarding the corrosion behavior of HEAs are suggested.
\end{abstract}

Keywords: high-entropy alloy; corrosion resistance; coating; aqueous environment

\section{Introduction}

Corrosion - the chemical/electrochemical interaction between materials and environmentsimpacts the proper function of materials, which rapidly leads to their failure during service. The cost of corrosion in the United States had reached $\$ 1$ trillion in 2013, which is $6.2 \%$ of the U.S. gross domestic product (GDP). Moreover, corrosion destroys more than three percent of the world's GDP [1]. Therefore, the investigation of corrosion behavior and the development of corrosion-resistant structural/functional materials are of enormous economic benefit. Among metallic materials, the noble metals, including $\mathrm{Ag}, \mathrm{Au}, \mathrm{Pt}$, etc., possess satisfactory corrosion resistance. However, their high costs and poor mechanical properties restrict their applications [2]. Hence, past research related to the development of corrosion-resistant materials has mainly focused on the other category of alloys including stainless steels, nickel-based alloys, titanium alloys, and so forth. The design principle of the above alloys follows the conventional path; through the addition of alloying elements in relatively low concentrations to one base element, the corrosion resistance is improved. The basic mechanism is that the addition of alloying elements, such as $\mathrm{Cr}, \mathrm{Ni}$, and/or Mo, results in the formation of protective passive films on the surface, which prevents further corrosion of the alloys underneath. The enhanced corrosion-resistant ability leads to their wide use in industry. However, along with the alloying process, the presence of precipitates, such as carbides, nitrides, and/or intermetallic compounds, impacts the corrosion behavior. For example, in stainless steels, the precipitation of $\mathrm{M}_{23} \mathrm{C}_{6}$ and/or sigma $(\sigma)$ phases deteriorate the corrosion resistance due to the formation of nearby $\mathrm{Cr}$-depleted zones, which are susceptible to the attack of anions $\left(\mathrm{Cl}^{-}\right)$, thus leading to localized corrosion [3,4]. Moreover, 
the insufficient high temperature-stability of the conventional alloys deteriorate the mechanical properties as well as the corrosion resistance [5], and hence restrict their application in extreme and highly-sensitive engineering service environments.

By breaking the classical alloy-design philosophy, the concept of high-entropy alloys (HEAs), which are defined as alloys that contain five or more principal elements in equal or near-equal atomic percent (wt \%), was proposed [6-10]. Because of the high mixing entropy effect, HEAs tend to form disordered solid solutions of face-centered cubic (FCC) $[8,11]$, body-centered cubic (BCC) $[8,11]$, or hexagonal closed-pack (HCP) $[8,11-14]$ structures, instead of complex intermetallic compounds. The random arrangement of multiple elements in solid solutions results in a particular locally-disordered chemical environment [15], which is expected to lead to unique corrosion-resistant properties. The corrosion behavior of HEAs in various aqueous environments (salt water, acid, high-temperature high-pressure water) has been investigated during the last decade [16-21]. The HEAs systems, which contain passivating elements, such as $\mathrm{Cr}, \mathrm{Ni}$, Mo, etc., revealed equivalent or superior corrosion-resistant properties compared with conventional alloys [16,17]. Furthermore, the exceptional properties, such as the combined noble strength-ductility [22,23], improved fatigue resistance [24-26], high fracture toughness [27,28], and high thermal stability [29], make HEAs attractive in many industrial fields, especially as superior structural alloys, which are highly demanded for extreme service environments such as in the nuclear, turbine, and aerospace industries.

Another aspect of taking advantage of the corrosion-resistant properties of HEAs is through surface coatings. From an economic aspect, the cost of bulk HEAs synthesized by arc melting or casting might be high, considering the addition of expensive alloying elements. However, surface coatings provide a solution to this problem. Recently, HEAs films on various steels, $\mathrm{Al}$ alloys, and Si were successfully obtained via laser cladding [30-33], electro-spark deposition [34], magnetron sputtering [35-37], etc. Through the use of surface coatings, a judicious combination of costs and properties is achieved. The HEAs films confer corrosion protection via the formation of barriers (stable passive films) to the penetration of corrodants and high ionic resistivity in surface layers to minimize electrochemical reactions under the coating. The combination of the good mechanical properties and novel corrosion resistance of the HEA film provides an outstanding cavitation-erosion-resistant property in salt water [38]. Similarly, the combined good irradiation and corrosion resistance make HEAs potential candidates for the coating of materials used in nuclear fuels and high pressure vessels [39]. Moreover, it is reported that an HEA film that has the same composition as the bulk material possesses even better corrosion-resistant properties [38], which might be attributed to the more homogeneous microstructure in the film.

Based on the recent investigation of the corrosion-resistant HEAs, this article summarized the corrosion-resistant properties of HEAs in various aqueous environments (salt water, acid, high-temperature high-pressure water) and the corrosion behavior of HEA coatings synthesized by various processing routes. The effects of environments, alloying elements, and processing methods on corrosion behavior are analyzed and discussed in detail. Furthermore, in order to gain an in-depth, fundamental understanding of corrosion behavior, thus leading to the design of highly corrosion-resistant HEAs, suggested future work is proposed.

\section{Review}

\subsection{Environmental and Alloying Effects on Corrosion Behavior}

The corrosion feature of metallic alloys is determined by the interactions between environments and materials. In terms of environments, the common service conditions in aqueous environments for corrosion-resistant materials include salt water, acid, as well as pressurized high-temperature water. Concerning materials, the corrosion-resistant property is usually altered by elemental alloying. Different elemental alloying can affect the corrosion resistance by changing the phase structure and elemental segregation, affecting the passive film property, shifting the nobility of the phases, and 
influencing the dissolution kinetics [2]. According to the two aspects that determined the corrosion behavior above, the corrosion-resistant properties of several HEAs were investigated, considering the environmental and elemental alloying effects over the past few decades, which will be discussed in detail below.

\subsubsection{Corrosion Behavior in Chloride-Containing Solutions}

To study the corrosion behavior of materials, the potentiodynamic-polarization test, which is a standard electrochemical technique, is usually used. The obtained parameters during the test usually include the corrosion potential $\left(E_{\text {corr }}\right)$, corrosion-current density $\left(i_{\text {corr }}\right)$, pitting potential $\left(E_{\text {pit }}\right)$ or breakdown potential $\left(E_{\mathrm{b}}\right)$, and passive current density $\left(i_{\text {pass }}\right)$, as shown in Figure 1 , which is a typical polarization curve in a 3.5 weight percent $(\mathrm{wt} \%) \mathrm{NaCl}$ solution. The $E_{\text {pit }}$ or $E_{\mathrm{b}}$ was determined by noting the potential at which a continuous increase in the anodic current density occurred, demonstrating the sustained localized dissolution of alloys due to the breakdown of the protected oxide/passive film formed on the surface. Therefore, the $E_{\mathrm{pit}} / E_{\mathrm{b}}$ could be used as an index of resistance to localized corrosion: a nobler value of $E_{\mathrm{pit}} / E_{\mathrm{b}}$ is associated with an increased localized corrosion resistance. The parameter, $i_{\text {corr }}$, can be used to calculate the average corrosion rates $\left(r_{\text {corr }}\right)$, which represent the general corrosion resistance. The equation is:

$$
\text { Corrosion rate }(\mathrm{mm} / \text { year })=3.27 \times 10^{-3} \times \frac{i_{\text {corr }}}{\rho} \times E W
$$

where $\rho$ is the density of the alloy (in $\left.\mathrm{g} / \mathrm{cm}^{3}\right), i_{\text {corr }}$ (in $\mu \mathrm{A} / \mathrm{cm}^{2}$ ) is the corrosion current density, and $E W$ is the equivalent weight of the alloy, which is given by:

$$
E W=\left(\sum \frac{n_{i} f_{i}}{W_{i}}\right)^{-1}
$$

where $n_{i}$ is the valence of the $i$ th element of the alloy, $f_{i}$ is the mass fraction of the $i$ th element in the alloy, and $W_{i}$ is the atomic weight of the $i$ th element in the alloy. In addition, the immersion test is another simple way to evaluate the corrosion rate, whose results can be compared with the corrosion rate calculated according to polarization test.

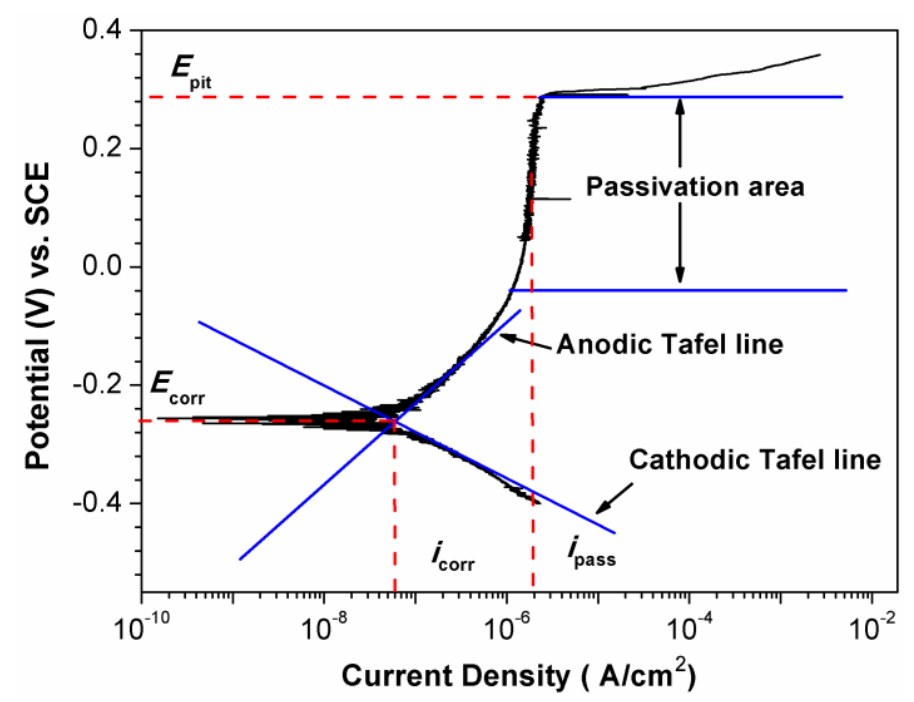

Figure 1. A typical potentiodynamic-polarization curve for the explanation of the parameters. $E_{\text {corr, }}$ corrosion potential; $i_{\text {corr }}$, corrosion current density; Passivation area, the potential range where a protective oxide film formed to prevent the continual metal from dissolving; $E_{\text {pit }}$, critical pitting potential; $i_{\text {pass }}$, current density in the passivation area. 
During the corrosion process in the chloride-containing solution, the detrimental $\mathrm{Cl}^{-}$anions would be adsorbed on the interface of the passive layer and the solution, and then penetrate through the oxide films. Successful native passive films can form protective layers over the surface, which act as barriers to the penetration of $\mathrm{Cl}^{-}$anions if the ingredients for passivation (alloying elements) are present in high enough concentrations [40]. Therefore, the property of the passive film is highly dependent on the alloying elements.

Lee et al. investigated the effect of the $\mathrm{Al}$ content on the corrosion behavior of $\mathrm{Al}_{x} \mathrm{CrFe}_{1.5} \mathrm{MnNi}_{0.5}$ HEAs [41]. The addition of aluminum significantly affected the evolution of phase structures. The microstructure changed from the FCC $+\alpha-\mathrm{FeCr}\left(\mathrm{CrFe}_{1.5} \mathrm{MnNi}_{0.5}\right)$, to $\mathrm{FCC}+\mathrm{BCC}\left(\mathrm{Al}_{0.3} \mathrm{CrFe}_{1.5} \mathrm{MnNi}_{0.5}\right)$, and eventually to $\mathrm{BCC}\left(\mathrm{Al}_{0.5} \mathrm{CrFe}_{1.5} \mathrm{MnNi}_{0.5}\right)$ structures as the $\mathrm{Al}$ content increased, which was in accordance with other studies [8,22]. The potential dynamic polarization test in a $1 \mathrm{M} \mathrm{NaCl}$ solution revealed that the $E_{\mathrm{pit}}$ values for the Al-containing alloys were significantly lower than that for the Al-free $\mathrm{CrFe}_{1.5} \mathrm{MnNi}_{0.5}$ alloy, which indicated that the addition of aluminum to the $\mathrm{Al}_{x} \mathrm{CrFe}_{1.5} \mathrm{MnNi}_{0.5}$ alloys reduced the resistance to pitting corrosion [41]. Moreover, the cyclic polarization test, which could be used to determine whether the alloys suffer from pitting, was conducted. The results indicated that the $\mathrm{CrFe}_{1.5} \mathrm{MnNi}_{0.5}$ alloy was not susceptible to localized corrosion, and that the passive film repaired itself. However, pitting of the $\mathrm{Al}_{0.3} \mathrm{CrFe}_{1.5} \mathrm{MnNi}_{0.5}$ alloy could be induced in a $\mathrm{Cl}^{-}$-containing solution. The pitting morphology observed by scanning electron microscopy (SEM) after the polarization tests also revealed the increased area of localized/pitting corrosion with increased $\mathrm{Al}$ content [41]. The negative effect of adding $\mathrm{Al}$ is attributed to the following facts. Firstly, the alloy with high $\mathrm{Al}$ and low $\mathrm{Cr}$ contents tended to form a porous oxide film on the surface, which could not offer protective barriers to the $\mathrm{Cl}^{-}$permeation. Secondly, the increased $\mathrm{Al}$ content encouraged the growth of the BCC phase, which generally is $\mathrm{Al}-\mathrm{Ni}$-rich and $\mathrm{Cr}$-depleted, thus leading to the increase of the elemental segregation degree. The increased volume fraction of the Cr-depleted BCC phase, whose passive film was less stable and possessed weaker corrosion-resistant ability, compared with the FCC phase, impacted the corrosion behavior.

The addition of $\mathrm{Al}$ in the $\mathrm{Al}_{x} \mathrm{CoCrFeNi}$ HEAs had a similar effect on the corrosion behavior in the chloride-containing solution [42]. The volume fraction of the Cr-depleted BCC phase increased with increased $\mathrm{Al}$ content. Moreover, increasing the $\mathrm{Al}$ content led to the formation of a dispersive, porous passive film on the surface of the alloy in a sulfuric acid. Once the chloride ions were added, the adsorbed chloride ions on the passive film would be combined and dissolved together with the metastable ion complexes, which is $\left[\mathrm{Al}\left(\mathrm{SO}_{4}\right)\right]^{+}\left(\mathrm{Al}+\mathrm{SO}_{4}{ }^{2-}=\left[\mathrm{Al}\left(\mathrm{SO}_{4}\right)\right]^{+}+3 \mathrm{e}^{-}\right)$and $/$or $\mathrm{Al}(\mathrm{OH}) \mathrm{SO}_{4}$ $\left(\mathrm{Al}+\mathrm{SO}_{4}{ }^{2-}+\mathrm{OH}^{-}=\mathrm{Al}(\mathrm{OH}) \mathrm{SO}_{4}+3 \mathrm{e}^{-}\right)$in a sulfuric acid. Spontaneously, the inner ion complexes of the passive layer move to the passive layer/solution interface in order to correlate with the applied potential. The inability of the $\mathrm{Cl}^{-}$to form oxides implies the continuous formation of metastable ion complexes, thus indicating the continuous dissolution of the alloy. When the $\mathrm{Al}$ content is high, the dispersive and porous passive film would lend a hand to the above process and then accelerate the dissolution of the alloys, which impacts the corrosion-resistant property [42]. Adding Al apparently reduces the ability to develop a protectable passive film on the alloy surface.

According to the above research, the corrosion behavior has a close relationship with the properties of the passive films. Although the addition of Al could increase the strength of the alloy, the pitting-corrosion resistance is inevitably impacted. In order to enhance the corrosion resistance of Al-containing HEAs, an anodic treatment to improve the property of the passive film was promoted [43]. The anodic treatment is to keep the sample being loaded at a certain potential in the passive region until the stable passive state is established, indicated by the stable, extremely low current density. After the anodic treatment in a $15 \mathrm{wt} \% \mathrm{H}_{2} \mathrm{SO}_{4}$ solution, the X-ray photoelectron spectroscopy (XPS) analyses revealed that the surface of the $\mathrm{Al}_{x} \mathrm{CrFe}_{1.5} \mathrm{MnNi}_{0.5}$ alloys was covered with a passive oxide film, which contained the aluminum and chromium oxide as the main passivating compounds. The oxide film effectively protected the alloys against pitting corrosion. This anodic treatment increased the corrosion resistance in the electrochemical-impedance-spectroscopy (EIS) 
measurements by two orders of magnitude, compared with the untreated one. Accordingly, the anodic treatment of the $\mathrm{Al}_{x} \mathrm{CrFe}_{1.5} \mathrm{MnNi}_{0.5}$ alloys effectively minimized the susceptibility to pitting corrosion in the chloride-containing solution [43].

As for the effect of the $\mathrm{Cu}$ addition on the corrosion behavior of HEAs, Hsu et al. investigated the corrosion behavior of the $\mathrm{FeCoNiCrCu}$ alloy in a $3.5 \mathrm{wt} \% \mathrm{NaCl}$ solution [44]. The surface appearance of the as-cast $\mathrm{FeCoNiCrCu}$ after the 30 day immersion test is shown in Figure 2, which revealed that the major types of corrosion were localized corrosion and pitting. The localized corrosion in $\mathrm{FeCoNiCrCu} \mathrm{u}_{0.5}$ and $\mathrm{FeCoNiCrCu}$ was found along the interdendrites, which was caused by the $\mathrm{Cu}$ segregation. Due to the weaker binding force (chemical-mixing enthalpy) with other elements such as $\mathrm{Fe}, \mathrm{Co}, \mathrm{Ni}$, and $\mathrm{Cr}, \mathrm{Cu}$ tends to segregate as clusters, forming $\mathrm{Cu}$-rich interdendrites and grain boundaries during the period of solidification [15]. Therefore, the $\mathrm{Cu}$-rich, $\mathrm{Cr}$-depleted interdendrites act as the anode coupled with the cathodic $\mathrm{Cu}$-depleted, $\mathrm{Cr}$-rich dendrites, forming the galvanic corrosion at the interdendrites. The volume fraction of the $\mathrm{Cu}$-rich, $\mathrm{Cr}$-depleted interdendrites increased with increased $\mathrm{Cu}$ content, causing more serious galvanic corrosion. Therefore, the passivation region of the FeCoNiCrCu $\mathrm{u}_{x}$ alloy narrowed with increased $\mathrm{Cu}$ content in the $3.5 \mathrm{wt} \% \mathrm{NaCl}$ solution [44]. In summary, the corrosion resistance generally decreases with the increase of the $\mathrm{Cu}$ concentration.
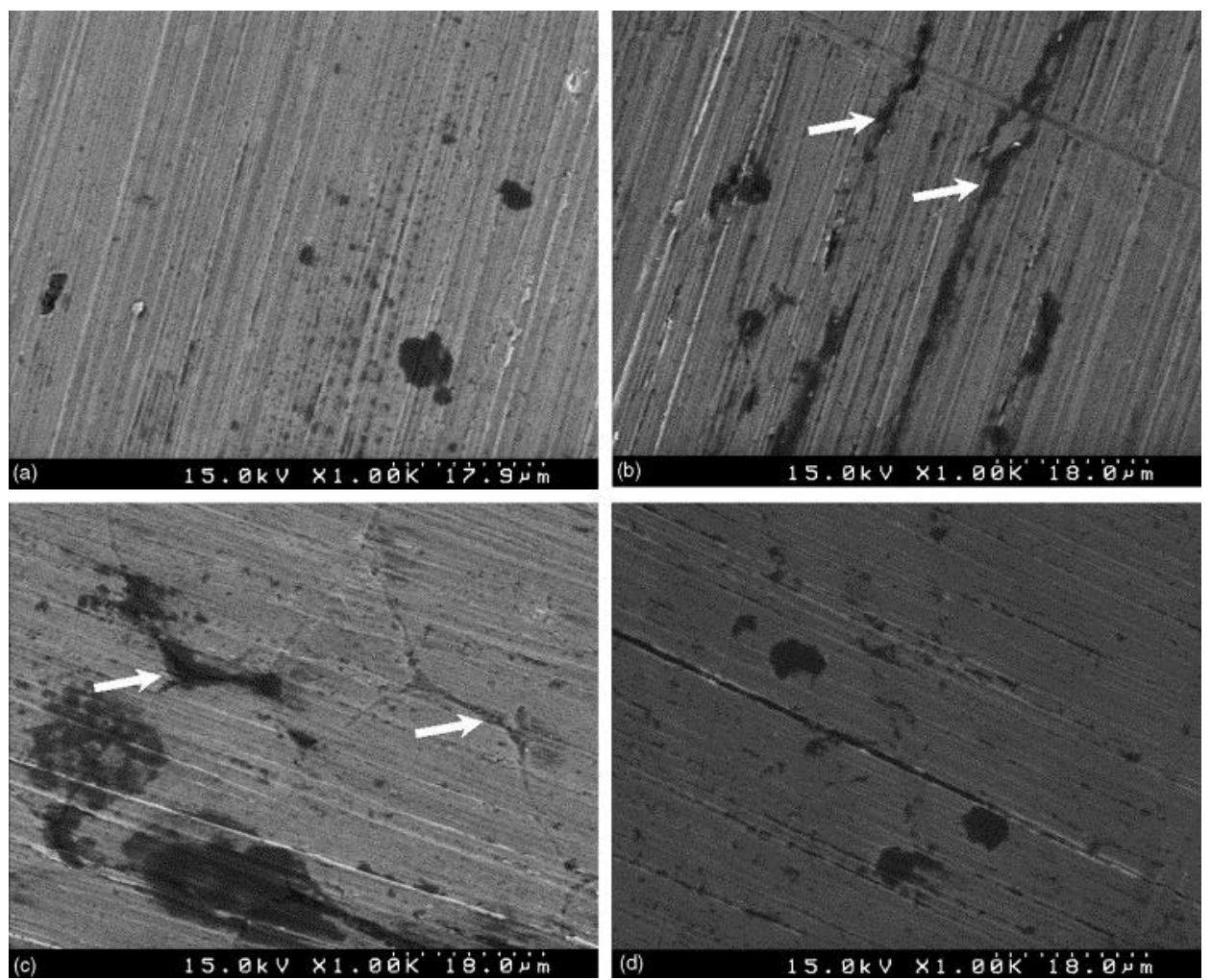

Figure 2. The surface appearance of alloys after immersion tests in the $3.5 \mathrm{wt} \% \mathrm{NaCl}$ solution for 30 days: (a) $\mathrm{FeCoNiCr}$; (b) $\mathrm{FeCoNiCrCu} .5$; (c) $\mathrm{FeCoNiCrCu}$; and (d) $304 \mathrm{~L}$ (white arrows point to the localized corrosion caused by electrochemical attack along the interdendrites) [44] (Reprinted with permission from Elsevier).

The effect of the addition of Mo to the $\mathrm{Co}_{1.5} \mathrm{CrFeNi}_{1.5} \mathrm{Ti}_{0.5} \mathrm{Mo}_{x}$ alloys on the corrosion behavior in a $1 \mathrm{M} \mathrm{NaCl}$ solution was investigated [45]. The addition of Mo is widely recognized for its beneficial effect on the corrosion resistance of stainless steels. Similarly, with Mo added, molybdenum species, which are mainly the ionic compound $\left(\mathrm{MoO}_{4}{ }^{2-}\right)$, would be adsorbed on the top of the material surface, acting as a barrier against the electrochemical attack. The cyclic-polarization test indicated that the Mo-free alloy tended to pit in the $1 \mathrm{M} \mathrm{NaCl}$. However, the Mo-containing alloys were not 
susceptible to pitting. The passivation region of $1.43 \mathrm{~V}$ of Mo-added alloys was much higher than the Mo-free alloy. However, it should be noted that the presence of the Cr-rich sigma $(\sigma)$ phase in the $\mathrm{Co}_{1.5} \mathrm{CrFeNi}_{1.5} \mathrm{Ti}_{0.5} \mathrm{Mo}_{x}(x=0.5$ and 0.8$)$ alloys led to the formation of the Cr-depleted area, thus reducing the passivation performance.

Another way to enhance the corrosion resistance, especially the resistance to pitting of HEAs in the chloride-containing solution, is by the addition of inhibitors [46,47]. The ions/molecules, which are added in appropriate concentrations to the solutions, act as pitting corrosion inhibitors by altering the $\mathrm{pH}$ or ionic content of active surface sites. The classical theory to explain the action of inhibitors is competitive adsorption between chloride and the inhibiting ions/molecules. The effect of the inorganic/organic inhibitor on the $E_{\text {pit }}$ of the $\mathrm{Co}_{1.5} \mathrm{CrFeNi}_{1.5} \mathrm{Ti}_{0.5} \mathrm{Mo}_{0.1} \mathrm{HEA}$ was investigated. The results showed that the added inhibitors all retard the occurrence of pitting corrosion. Some of them inhibited the propagation of stable pits, and others of them restrained the nucleation of stable pits [46]. Moreover, the increasing concentration of $\mathrm{SO}_{4}{ }^{2-}$ also had a positive effect on improving the pitting-corrosion resistance [47].

Table 1 summarizes the parameters obtained though the potentiodynamic polarization tests of HEAs in salt water. As discussed above, it can be seen from the table that with increasing the $\mathrm{Al}$ or $\mathrm{Cu}$ content, the corrosion current density increases while the pitting potential decreases, representing the degradation of the corrosion resistance. The addition of Mo firstly improves and then decreases the corrosion resistance due to the formation of the Cr-rich $\sigma$ phase.

Table 1. Electrochemical parameters of high-entropy alloys (HEAs) in the chloride-containing solution at room temperature.

\begin{tabular}{|c|c|c|c|c|c|}
\hline Alloy & Solution & $E_{\text {corr }}{ }^{1}\left(\mathrm{~V}_{\mathrm{SHE}}{ }^{4}\right)$ & $i_{\text {corr }}{ }^{2}\left(\mu \mathrm{A} / \mathrm{cm}^{2}\right)$ & $E_{\text {pit }}{ }^{3}\left(\mathrm{~V}_{\mathrm{SHE}}\right)$ & Reference \\
\hline $\mathrm{CrFe}_{1.5} \mathrm{MnNi}_{0.5}$ & $1 \mathrm{M} \mathrm{NaCl}$ & -0.39 & 0.45 & 0.019 & [41] \\
\hline $\mathrm{Al}_{0.3} \mathrm{CrFe}_{1.5} \mathrm{MnNi}_{0.5}$ & $1 \mathrm{M} \mathrm{NaCl}$ & -0.40 & 0.69 & -0.15 & [41] \\
\hline $\mathrm{Al}_{0.5} \mathrm{CrFe}_{1.5} \mathrm{MnNi}_{0.5}$ & $1 \mathrm{M} \mathrm{NaCl}$ & -0.50 & 1.02 & -0.12 & [41] \\
\hline $\mathrm{FeCoNiCr}$ & $0.6 \mathrm{M} \mathrm{NaCl}$ & -0.46 & 0.035 & 0.31 & [44] \\
\hline $\mathrm{FeCoNiCrCu} \mathrm{u}_{0.5}$ & $0.6 \mathrm{M} \mathrm{NaCl}$ & -0.49 & 0.72 & 0.09 & [44] \\
\hline $\mathrm{FeCoNiCrCu}$ & $0.6 \mathrm{M} \mathrm{NaCl}$ & -0.53 & 1.23 & 0.08 & [44] \\
\hline $\mathrm{Co}_{1.5} \mathrm{CrFeNi}_{1.5} \mathrm{Ti}_{0.5}$ & $1 \mathrm{M} \mathrm{NaCl}$ & -0.44 & 0.57 & 0.33 & [45] \\
\hline $\mathrm{Co}_{1.5} \mathrm{CrFeNi}_{1.5} \mathrm{Ti}_{0.5} \mathrm{Mo}_{0.1}$ & $1 \mathrm{M} \mathrm{NaCl}$ & -0.38 & 0.13 & 1.21 & [45] \\
\hline $\mathrm{Co}_{1.5} \mathrm{CrFeNi}_{1.5} \mathrm{Ti}_{0.5} \mathrm{Mo}_{0.5}$ & $1 \mathrm{M} \mathrm{NaCl}$ & -0.49 & 0.20 & 1.16 & [45] \\
\hline $\mathrm{Co}_{1.5} \mathrm{CrFeNi}_{1.5} \mathrm{Ti}_{0.5} \mathrm{Mo}_{0.8}$ & $1 \mathrm{M} \mathrm{NaCl}$ & -0.55 & 0.41 & 1.18 & {$[45]$} \\
\hline
\end{tabular}

\subsubsection{Corrosion Behavior in Acid Solutions}

In the $\mathrm{H}_{2} \mathrm{SO}_{4}$ solution, the alloying effects on the corrosion behavior of HEAs, including the addition of $\mathrm{Al}, \mathrm{Cu}, \mathrm{Mo}$, and $\mathrm{B}$, were investigated. In contrast to the chloride-containing solution, the absence of $\mathrm{Cl}^{-}$reduces the possibility of the pitting potential. However, the high concentration of $\mathrm{H}^{+}$influences the properties of the oxide film, thus affecting the corrosion behavior, and especially the general corrosion resistance.

The effect of the $\mathrm{Al}$ content on the corrosion behavior of the $\mathrm{Al}_{x} \mathrm{CrFe}_{1.5} \mathrm{MnNi}_{0.5} \mathrm{HEAs}$ in $0.5 \mathrm{M}$ $\mathrm{H}_{2} \mathrm{SO}_{4}$ was also investigated by Lee et al. [41]. They found that with increasing the $\mathrm{Al}$ content, the $E_{\text {corr }}$ decreased, and $i_{\text {corr }}$ and $i_{\text {pass }}$ increased, indicating the reduced general corrosion resistance in the $\mathrm{H}_{2} \mathrm{SO}_{4}$ solution. The EIS tests were conducted at the open circuit potential (OCP) to study the resistance of the passive film. The charge-transfer resistance decreased with increased Al content, revealing the decreased corrosion resistance. Moreover, the second capacitive loop of the Al-containing alloy in the Nyquist plot indicated the formation of the adsorptive film on the alloy's surface [41]. The adsorptive complexes formed in the acid medium were confirmed as the production of the dissolution of $\mathrm{Al}$ in the HEAs by the following mechanism:

$$
\mathrm{Al}+\mathrm{H}_{2} \mathrm{O}=\mathrm{Al}(\mathrm{OH})_{\mathrm{ad}}+\mathrm{H}^{+}+\mathrm{e}^{-}
$$




$$
\mathrm{Al}(\mathrm{OH})_{\mathrm{ad}}+5 \mathrm{H}_{2} \mathrm{O}+\mathrm{H}^{+}=\mathrm{Al}^{3+} \boldsymbol{- 6} 6 \mathrm{H}_{2} \mathrm{O}+2 \mathrm{e}^{-}
$$

therefore, the addition of the $\mathrm{Al}$ content caused the formation of the porous corrosion product to cover the alloy, and the thickness of the adsorptive layer increases with the amount of $\mathrm{Al}$ in the alloy. Moreover, the increased $\mathrm{Al}$ content leads to the increased volume fraction of the Al-rich, $\mathrm{Cr}$-depleted BCC phase, whose passive film is more porous and less protective, resulting in the decreased corrosion resistance, as can be seen in Figure 3. The addition of $\mathrm{Al}$ in the $\mathrm{Al}_{x} \mathrm{CoCrFeNi}$ alloys has a similar effect on the corrosion behavior in the $0.5 \mathrm{M} \mathrm{H}_{2} \mathrm{SO}_{4}$ [42]. Due to the spontaneous passivation of the $\mathrm{Al}$ element, the corrosion rate was reflected by the $i_{\text {pass. }}$. Similarly, the EIS results indicated that with increasing the $\mathrm{Al}$ content, the passive film became thicker and dispersive. Therefore, $i_{\text {pass }}$ increased with increased $\mathrm{Al}$ content, reflecting the inferior corrosion resistance with added Al. Signs of corrosion can be observed in the Al-Ni-rich BCC phase, according to the surface morphology of the alloys after the immersion tests.
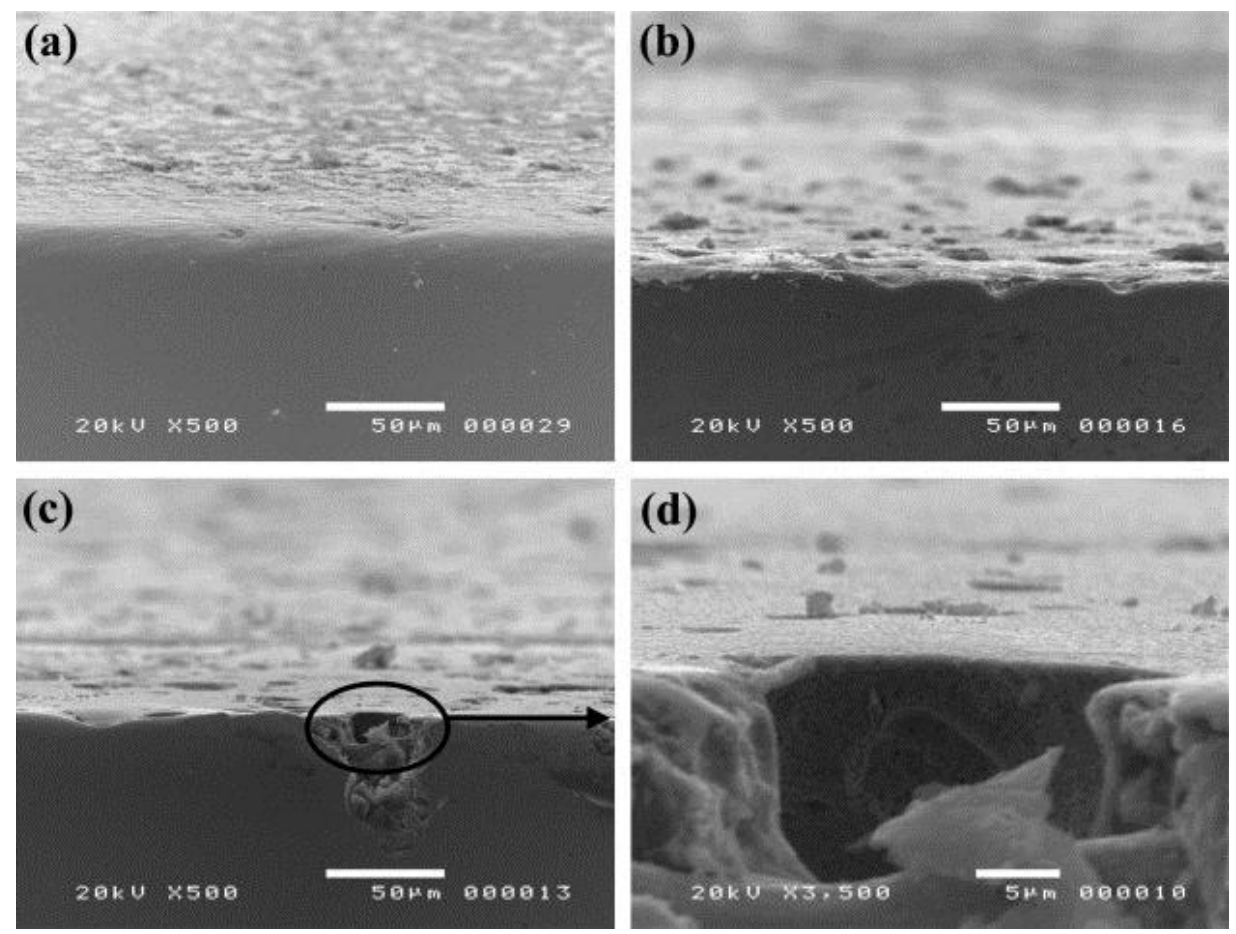

Figure 3. SEM micrographs for the $\mathrm{Al}_{x} \mathrm{CrFe}_{1.5} \mathrm{MnNi}_{0.5}$ alloys with varying amounts of aluminum content (a) $x=0$; (b) $x=0.3 \mathrm{~mol}$, (c) $x=0.5 \mathrm{~mol}$; (d) higher magnification of micrograph (c) after anodic polarization exceeded the breakdown potential (>1.25 $\mathrm{V}_{\mathrm{SHE}}$ ) in $0.5 \mathrm{M} \mathrm{H}_{2} \mathrm{SO}_{4}$ [41] (Reprinted with permission from Elsevier).

Ren et al. studied the influence of the $\mathrm{Cu}$ addition on the corrosion behavior of the $\mathrm{CoCrFeNiCu}$ alloy in the $1 \mathrm{M} \mathrm{H}_{2} \mathrm{SO}_{4}$ [48]. Similar to the case in the $\mathrm{NaCl}$ solution, due to the segregation of $\mathrm{Cu}$, the interaction between the $\mathrm{Cu}$-rich, $\mathrm{Cr}$-depleted inter-dendrite and the $\mathrm{Cr}$-rich, $\mathrm{Cu}$-depleted dendrite led to galvanic corrosion. As a result, $\mathrm{Cu}$ was dissolved in the solution. The uniform structure with a low $\mathrm{Cu}$ content reduced the effect of galvanic corrosion. On the contrary, the non-uniform structure and high elemental segregation will result in more serious galvanic corrosion. The increased $\mathrm{Cu}$ content enhanced the degree of elemental segregation, but on the other hand, led to the formation of a mixed structure. Therefore, the addition of $\mathrm{Cu}$ caused the galvanic corrosion and degraded the corrosion resistance. The addition of $\mathrm{Mo}$ to the $\mathrm{Co}_{1.5} \mathrm{CrFeNi}_{1.5} \mathrm{Ti}_{0.5} \mathrm{Mo}_{x}$ was detrimental to the general corrosion resistance in $0.5 \mathrm{M} \mathrm{H}_{2} \mathrm{SO}_{4}$ [45]. The $i_{\text {corr }}$ and $i_{\text {pass }}$ values of the Mo-free alloy were significantly lower than those of the Mo-containing alloys. Therefore, the Mo-free alloy was more resistant to general corrosion. The addition of Mo improved the corrosion resistance in the $\mathrm{NaCl}$ solution (as mentioned 
above) but impacted the corrosion behavior in the $\mathrm{H}_{2} \mathrm{SO}_{4}$ solution. The reason is that according to the Pourbaix diagram [49], the formation of the protective molybdenum species on the surface is impossible when considering the $0.5 \mathrm{M} \mathrm{H}_{2} \mathrm{SO}_{4}$ acid condition. Therefore, the formation of the $\mathrm{Cr}$-rich sigma phase with increased Mo content led to the occurrence of the Cr-depleted areas nearby, which were more prone to corrosion. The addition of $\mathrm{B}$ to the $\mathrm{Al}_{0.5} \mathrm{CoCrCuFeNiB}$ alloy was verified to lead to the formation of $\mathrm{Cr}, \mathrm{Fe}$, and Co-rich borides, thus decreasing the $\mathrm{Cr}$ content in the matrix [50]. The XPS test confirmed that the predominant surface oxide was that of a $\mathrm{Cr}_{2} \mathrm{O}_{3}$ based film. A native chromium oxide film protected the alloy from dissolution. Therefore, due to the formation of $\mathrm{Cr}$-rich borides, the Cr-depleted matrix would suffer from corrosion, and the corrosion-resistant property was reduced with increased $B$ content.

Table 2 summarizes the parameters obtained through the potentiodynamic-polarization tests of HEAs in the acid solutions, as discussed above. The additions of $\mathrm{Al}, \mathrm{Cu}, \mathrm{Mo}$, and $\mathrm{B}$ to different HEA systems all impact the corrosion resistance, which are reflected by the increase of $i_{\text {corr }}$ and the decrease of $\Delta E_{\mathrm{b}}$.

Table 2. Electrochemical parameters of HEAs in the acid solution at room temperature.

\begin{tabular}{|c|c|c|c|c|c|}
\hline Alloy & Solution & $E_{\text {corr }}{ }^{1}\left(\mathrm{~V}_{\mathrm{SHE}}{ }^{4}\right)$ & $i_{\text {corr }}{ }^{2}\left(\mu \mathrm{A} / \mathrm{cm}^{2}\right)$ & $\Delta E_{\mathrm{b}}{ }^{3}\left(\mathrm{~V}_{\mathrm{SHE}}\right)$ & Reference \\
\hline $\mathrm{CrFe}_{1.5} \mathrm{MnNi}_{0.5}$ & $0.5 \mathrm{M} \mathrm{H}_{2} \mathrm{SO}_{4}$ & -0.23 & 31.4 & 1.227 & [41] \\
\hline $\mathrm{Al}_{0.3} \mathrm{CrFe}_{1.5} \mathrm{MnNi}_{0.5}$ & $0.5 \mathrm{M} \mathrm{H}_{2} \mathrm{SO}_{4}$ & -0.19 & 73.9 & 1.176 & [41] \\
\hline $\mathrm{Al}_{0.5} \mathrm{CrFe}_{1.5} \mathrm{MnNi}_{0.5}$ & $0.5 \mathrm{M} \mathrm{H}_{2} \mathrm{SO}_{4}$ & -0.21 & 68.2 & 1.114 & [41] \\
\hline CoCrFeNi & $0.5 \mathrm{M} \mathrm{H}_{2} \mathrm{SO}_{4}$ & -0.081 & 15.8 & 1.098 & [42] \\
\hline $\mathrm{Al}_{0.25} \mathrm{CoCrFeNi}$ & $0.5 \mathrm{M} \mathrm{H}_{2} \mathrm{SO}_{4}$ & -0.095 & 16.7 & 1.092 & [42] \\
\hline $\mathrm{Al}_{0.5} \mathrm{CoCrFeNi}$ & $0.5 \mathrm{M} \mathrm{H}_{2} \mathrm{SO}_{4}$ & -0.084 & 13.4 & 1.083 & [42] \\
\hline $\mathrm{AlCoCrFeNi}$ & $0.5 \mathrm{M} \mathrm{H}_{2} \mathrm{SO}_{4}$ & -0.094 & 13.1 & 1.09 & [42] \\
\hline $\mathrm{Co}_{1.5} \mathrm{CrFeNi}_{1.5} \mathrm{Ti}_{0.5}$ & $0.5 \mathrm{M} \mathrm{H}_{2} \mathrm{SO}_{4}$ & -0.092 & 30 & 1.13 & [45] \\
\hline $\mathrm{Co}_{1.5} \mathrm{CrFeNi}_{1.5} \mathrm{Ti}_{0.5} \mathrm{Mo}_{0.1}$ & $0.5 \mathrm{M} \mathrm{H}_{2} \mathrm{SO}_{4}$ & -0.071 & 78 & 1.112 & [45] \\
\hline $\mathrm{Co}_{1.5} \mathrm{CrFeNi}_{1.5} \mathrm{Ti}_{0.5} \mathrm{Mo}_{0.5}$ & $0.5 \mathrm{M} \mathrm{H}_{2} \mathrm{SO}_{4}$ & -0.064 & 62 & 1.109 & [45] \\
\hline $\mathrm{Co}_{1.5} \mathrm{CrFeNi}_{1.5} \mathrm{Ti}_{0.5} \mathrm{Mo}_{0.8}$ & $0.5 \mathrm{M} \mathrm{H}_{2} \mathrm{SO}_{4}$ & -0.070 & 69 & 1.109 & [45] \\
\hline $\mathrm{Cu}_{0.5} \mathrm{CrFeNiMn}$ & $1 \mathrm{M} \mathrm{H}_{2} \mathrm{SO}_{4}$ & -0.073 & 20.9 & 0.050 & [48] \\
\hline $\mathrm{CuCr}_{0.5} \mathrm{FeNi}_{0.5} \mathrm{Mn}$ & $1 \mathrm{M} \mathrm{H}_{2} \mathrm{SO}_{4}$ & -0.090 & 40.2 & 0.035 & [48] \\
\hline $\mathrm{Al}_{0.5} \mathrm{CoCrCuFeNi}$ & $1 \mathrm{M} \mathrm{H}_{2} \mathrm{SO}_{4}$ & -0.115 & 78.7 & 0.348 & [50] \\
\hline $\mathrm{Al}_{0.5} \mathrm{CoCrCuFeNiB}{ }_{0.2}$ & $1 \mathrm{M} \mathrm{H}_{2} \mathrm{SO}_{4}$ & -0.121 & 103 & 0.336 & [50] \\
\hline
\end{tabular}

\subsubsection{Corrosion Behavior in High-Temperature High-Pressure Water}

The high thermal stability and novel corrosion resistance provide HEAs with the capacity to be applied in supercritical service environments such as high-temperature, high-pressure water environments. Therefore, the oxidation behavior of the $\mathrm{Al}_{x} \mathrm{CoCrFeNi}(x=0.15$ and 0.4$) \mathrm{HEAs}$, compared with the HR3C steel $(25 \mathrm{Cr}-20 \mathrm{Ni}-\mathrm{Nb}-\mathrm{N})$ in the supercritical water at 550 and $600{ }^{\circ} \mathrm{C}$ was investigated [20]. The surface morphologies showed that in all the alloys, spinel-type $(\mathrm{Fe}, \mathrm{Cr})_{3} \mathrm{O}_{4}$ oxides formed the dense oxide films. However, the oxide particles of HEAs were more homogenized and had smaller sizes. The SEM/EDS analyses along the cross section of the oxide films revealed that the oxide film formed on the HEAs was much thinner than that for the steel. The thinner oxide films with more homogeneous and smaller sizes of oxide particles on HEAs represents the superior oxidation resistance of HEAs compared to the HR3C steel in the supercritical water environment. The increase of the Al content influenced the structure of the oxide film. The oxide film of the low $\mathrm{Al}$ content $\left(\mathrm{Al}_{0.15} \mathrm{CoCrFeNi}\right)$ showed a duplex layer structure with a $\mathrm{Fe}_{3} \mathrm{O}_{4}$ outer layer and a $\mathrm{FeCr}_{2} \mathrm{O}_{4}$ inner layer, while the oxide film on the $\mathrm{Al}_{0.4} \mathrm{CoCrFeNi}$ alloy mainly consisted of a single $\mathrm{FeCr}_{2} \mathrm{O}_{4}$ layer.

Xiang et al. compared the repassivation rate, which can be used as an index to evaluate the sensitization to stress corrosion, among three HEAs, $\mathrm{Co}_{1.5} \mathrm{CrFeNi}_{1.5} \mathrm{Ti}_{0.5} \mathrm{Mo}_{0.1}, \mathrm{AlCoCrFeNiSi}_{0.1}$, TaNbHfZrTi, and a commercial alloy 690TT (nickel-based alloy) in $300{ }^{\circ} \mathrm{C} 10 \mathrm{MPa}$ water with $1500 \mathrm{mg} / \mathrm{kg} \mathrm{B}$ and $2.3 \mathrm{mg} / \mathrm{kg} \mathrm{Li}$ [39]. The test environment was similar to the service condition in the pressurized water reactor (PWR) primary pipeline. The higher repassivation rate indicates greater 
resistance to stress corrosion. The repassivation rates of these four alloys in the high-temperature pressurized water were ranked with the following sequence: TaNbHfZrTi $>\mathrm{Co}_{1.5} \mathrm{CrFeNi}_{1.5} \mathrm{Ti}_{0.5} \mathrm{Mo}_{0.1}>$ $690 \mathrm{TT}>\mathrm{AlCoCrFeNiSi}_{0.1}$. The higher repassivation rate and better stress-corrosion resistance of the TaNbHfZrTi and $\mathrm{Co}_{1.5} \mathrm{CrFeNi}_{1.5} \mathrm{Ti}_{0.5} \mathrm{Mo}_{0.1}$ HEAs demonstrate that HEAs could be used as components or coating alloys to guarantee the safety of nuclear power plants in service.

\subsection{Corrosion Resistance of HEA Coatings}

During the last 5 years, HEA coatings of various thicknesses have been successfully obtained by laser cladding, electro-spark deposition, chemical-vapour deposition, and magnetron sputtering. Most of the HEA coatings revealed a homogeneous microstructure, satisfactory thermal stability, and wear resistance. In this review, the corrosion properties of HEA coatings of different thickness ranges (millimeter and micrometer) are summarized and discussed.

\subsubsection{Coating by Laser Cladding}

Uniform, dense, and well-bonded HEA coatings have been fabricated by laser cladding. The advantages of laser cladding include the high-energy density, small thermal effects on the substrate, low dilution of the substrate, and the rapid heating and cooling process. Therefore, laser cladding is suitable for the synthesis of HEA coatings with thicknesses reaching the millimeter range [51]. The alloying and processing parameters are the main two aspects that influence the properties, including the corrosion resistance of the coatings, and will be discussed in detail below.

For the effect of alloying elements, Ye et al. investigated the corrosion property of $\mathrm{Al}_{x} \mathrm{CoCrCuFeNi}$ HEA coatings [52]. The HEA coatings successfully prepared by laser cladding on AISI 1045 steel (0.43-0.50 wt \% C, 0.60-0.90 wt \% Mn) were proven to have the FCC and BCC structures. The microstructure contained dendrites and interdendrites, which had the same structure as the cast sample. However, the degree of $\mathrm{Cu}$ segregation in the interdendrite was much lower than that in the cast sample [52]. The relatively homogeneous elemental distribution tended to improve the corrosion resistance. The $\mathrm{Al}_{x} \mathrm{CoCrCuFeNi}$ coatings possessed better corrosion resistance than the $314 \mathrm{~L}$ stainless steel (18 wt \% Cr, 9 wt \% Ni, 1 wt \% Si, 2 wt \% Mn) in the $0.05 \mathrm{~mol} / \mathrm{L}$ $\mathrm{HCl}$ [52]. Qiu et al. studied the effects of $\mathrm{Ti}$ and $\mathrm{Ni}$ contents on the corrosion behavior of the $\mathrm{Al}_{2} \mathrm{CoCrCuFeNiTi}$ and $\mathrm{Al}_{2} \mathrm{CoCrCuFeTiNi}$ coatings deposited on Q235 carbon steel $(0.17$ wt $\% \mathrm{C}$, 0.30 wt \% Si, 0.35-0.80 wt \% Mn) [53,54]. The HEA coatings consisted of cladding, bounding, and heat-affected zones. The coating had good metallurgical bonding with the substrate. The relatively simple and fine microstructure (FCC + BCC phases with equiaxed grains and columnar crystals) and reduced ingredient segregation, which were attributed to the rapid-cooling process and the high-entropy effect, reduced the accelerated corrosion effect caused by the formation of the galvanic cell. Therefore, both the $\mathrm{Al}_{2} \mathrm{CoCrCuFeNiTi}$ and $\mathrm{Al}_{2} \mathrm{CoCrCuFeTiNi}$ coatings showed novel corrosion resistance. Compared with the Q235 steel, the corrosion current density was reduced by 1-2 orders

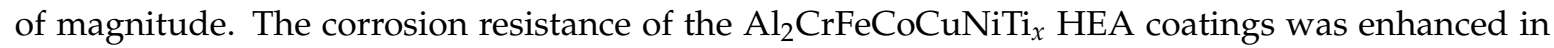
$0.5 \mathrm{M} \mathrm{HNO}_{3}$ solutions by increasing the Ti content [53]. However, with the increase of the Ni content, the corrosion resistance first increased and then decreased in the $0.6 \mathrm{M} \mathrm{NaCl}$ [54]. The effects of Si (1.2 mol \%), Mn (1.2 mol \%), and Mo (1.2 mol \%) additions on the CoCrCuFeNi HEA coating clad on the top of the Q235 steel were investigated [51]. The multi-component alloy coating was found to be a simple FCC solid solution with less component segregation without the additions of Si, Mn, and Mo. However, the coating and substrate were badly connected, which indicated that the coating quality was very poor. After the additions, the coating quality was greatly improved. Although the microstructure transformed to the dendrite due to the slight increase in the component segregation, the corrosion resistance of the CoCrCuFeNi HEA coating was still better than the typical nickel-based super alloy $(\mathrm{NiCrSiB})$ coating in $5 \mathrm{vol} \% \mathrm{H}_{2} \mathrm{SO}_{4}$ solutions.

For the effect of the processing parameters of laser cladding on the corrosion behavior of HEA coatings, Qiu et al. found that with the increase of the laser scanning speed during coating, the 
corrosion resistance of the $\mathrm{AlCrFeCuCo} \mathrm{HEA}$ coating on the Q235 steel first increased and then decreased [55]. The reason for this trend was that with the increase of the scan speed, less laser energy was absorbed by the cladding layer material, and the fast cooling rate made the layer surface become smooth and dense, which benefited the corrosion resistance. However, if the scan speed was too fast, the rough cladding layer surface led to poor corrosion resistance. The effects of energy input and layer number on the corrosion behavior of the CoCrFeNi coating was studied [33]. With $\mathrm{Al}$ as the substrate, the higher energy input combined with the multi-layered coating could reduce the dilution from the substrate (which leads to the formation of the heterogeneous composition and microstructure), and, therefore, enhanced the formation of HEAs throughout the coating, avoided the local micro-galvanic cell formation, and resulted in the superior corrosion resistance in the $3.5 \mathrm{wt} \%$ $\mathrm{NaCl}$ solution [33]. The proper selection of processing parameters, including the laser power, scanning speed, and laser spot radius led to the successful AlCoCrFeNi HEA coating with a simple BCC phase on the 304 stainless steel [38]. The AlCoCrFeNi coating had good metallurgical bonding with the substrate. The corrosion resistance in the $3.5 \mathrm{wt} \% \mathrm{NaCl}$ solution and the cavitation erosion resistance were highly improved.

Besides laser cladding, electro-spark deposition could also synthesize the HEA coatings with thicknesses reaching the millimeter range. The AlCoCrFeNi coating that was deposited on the AISI 1045 steel by the electro-spark process demonstrated an excellent corrosion-resistant property, which was better than the cast alloy with the same composition in $1 \mathrm{M} \mathrm{NaCl}$ [34]. The noble $E_{\text {corr }}$ and low $i_{\text {corr }}$ values, which were about an order of magnitude lower than that of the 1045 steel, were attributed to the homogeneous composition/microstructure and relatively-high Cr-oxide and Al-oxide contents at the surface.

Table 3 summarized the parameters obtained through the potentiodynamic-polarization tests of HEA coatings in aqueous environments at room temperature. As discussed above, the addition of $\mathrm{Al}$ to the $\mathrm{Al}_{x} \mathrm{CoCrFeNi}$ coatings improves the corrosion resistance. The addition of $\mathrm{Ti}$ also enhances the corrosion resistance of the $\mathrm{Al}_{2} \mathrm{CrFeNiCoCuTi} x$ alloys. The addition of $\mathrm{Ni}$ firstly improves and then impacts the corrosion behavior of the $\mathrm{Al}_{2} \mathrm{CrFeCoCuTiNi}$ coatings. The $i_{\text {corr }}$ of the $\mathrm{AlCoCrFeNi}$ coating is extremely low, representing an outstanding corrosion resistance.

Table 3. Electrochemical parameters of HEAs coatings in the aqueous environment at room temperature.

\begin{tabular}{|c|c|c|c|c|}
\hline Alloy & Solution & $E_{\text {corr }}{ }^{1}\left(\mathrm{~V}_{\mathrm{SCE}}{ }^{3}\right)$ & $i_{\text {corr }}{ }^{2}\left(\mu \mathrm{A} / \mathrm{cm}^{2}\right)$ & Reference \\
\hline $\mathrm{AlCoCrFeNi}$ & $0.05 \mathrm{M} \mathrm{HCl}$ & -0.55 & 29.2 & [52] \\
\hline $\mathrm{Al}_{1.3} \mathrm{CoCrFeNi}$ & $0.05 \mathrm{M} \mathrm{HCl}$ & -0.58 & 47.9 & [52] \\
\hline $\mathrm{Al}_{1.5} \mathrm{CoCrFeNi}$ & $0.05 \mathrm{M} \mathrm{HCl}$ & -0.92 & 31.4 & [52] \\
\hline $\mathrm{Al}_{1.8} \mathrm{CoCrFeNi}$ & $0.05 \mathrm{M} \mathrm{HCl}$ & -0.67 & 7.6 & [52] \\
\hline $\mathrm{Al}_{2} \mathrm{CoCrFeNi}$ & $0.05 \mathrm{M} \mathrm{HCl}$ & -0.66 & 3.7 & [52] \\
\hline $\mathrm{Al}_{2} \mathrm{CrFeNiCoCu}$ & $0.5 \mathrm{M} \mathrm{HNO}_{3}$ & -0.18 & 38 & [53] \\
\hline $\mathrm{Al}_{2} \mathrm{CrFeNiCoCuTi}{ }_{0.5}$ & $0.5 \mathrm{M} \mathrm{HNO}_{3}$ & -0.30 & 22 & [53] \\
\hline $\mathrm{Al}_{2} \mathrm{CrFeNiCoCuTi}{ }_{1}$ & $0.5 \mathrm{M} \mathrm{HNO}_{3}$ & -0.33 & 7.3 & [53] \\
\hline $\mathrm{Al}_{2} \mathrm{CrFeNiCoCuTi}{ }_{1.5}$ & $0.5 \mathrm{M} \mathrm{HNO}_{3}$ & -0.30 & 4.4 & [53] \\
\hline $\mathrm{Al}_{2} \mathrm{CrFeNiCoCuTi} 2$ & $0.5 \mathrm{M} \mathrm{HNO}_{3}$ & -0.15 & 2.7 & [53] \\
\hline $\mathrm{Al}_{2} \mathrm{CrFeCoCuTi}$ & $0.6 \mathrm{M} \mathrm{NaCl}$ & -0.51 & 68 & [54] \\
\hline $\mathrm{Al}_{2} \mathrm{CrFeCoCuTiNi} i_{0.5}$ & $0.6 \mathrm{M} \mathrm{NaCl}$ & -0.43 & 32 & [54] \\
\hline $\mathrm{Al}_{2} \mathrm{CrFeCoCuTiNi}{ }_{1}$ & $0.6 \mathrm{M} \mathrm{NaCl}$ & -0.22 & 13 & [54] \\
\hline $\mathrm{Al}_{2} \mathrm{CrFeCoCuTiNi}{ }_{1.5}$ & $0.6 \mathrm{M} \mathrm{NaCl}$ & -0.48 & 64 & [54] \\
\hline $\mathrm{Al}_{2} \mathrm{CrFeCoCuTiNi} 2$ & $0.6 \mathrm{M} \mathrm{NaCl}$ & -0.50 & 67 & [54] \\
\hline $\mathrm{CoCrCuFeNi}$ & $0.5 \mathrm{M} \mathrm{H}_{2} \mathrm{SO}_{4}$ & -0.32 & 21.9 & [55] \\
\hline $\mathrm{AlCoCrFeNi}$ & $0.6 \mathrm{M} \mathrm{NaCl}$ & -0.17 & 0.073 & [38] \\
\hline
\end{tabular}

\subsubsection{Coating by Magnetron Sputtering}

Recently, the HEA coatings composed of homogeneous nanoparticles of simple structures were obtained through magnetron sputtering. A perfect dense and smooth AlCoCuFeNiV HEA coating was 
obtained by magnetron sputtering [36]. The synthesized thin films could be used as the wear-resistant coatings in corrosive medium environments, such as in the petrochemical industry and marine industry. The coating exhibited a single FCC solid solution. As the deposition time increased, the thickness of the coating and the size of the nanoparticles increased. The coating had a relatively-high Young's modulus up to $189 \mathrm{GPa}$. Attributed to the fact that there was almost no elemental segregation in the simple FCC structure, all coatings with various thicknesses exhibited better corrosion resistance than the 201 stainless steel (16-18 wt \% Cr, 3.5-5.5 wt \% Ni, 5.5-7.5 wt \% Mn) in acid and salt corrosion media, providing a promising usage of HEA coatings as anti-corrosion protective materials. Similar to the AlCoCuFeNiV HEA coating, the AlCoCrCuFeMn coating fabricated by magnetron sputtering also obtained homogeneous nano-grains with a single FCC structure, and possessed better corrosion-resistant ability than the 201 stainless steel [37]. The corrosion property of HEA coatings synthesized by magnetron sputtering has not been investigated widely, but because of the outstanding homogenization effect of sputtering and the satisfactory corrosion resistance, as discussed above, the study of HEA coatings by magnetron sputtering will attract more attention in future studies.

\subsection{Heat-Treatment Effect}

Theoretically, the reason for the formation of the simple solid-solution in HEAs is mainly due to the high configurational entropy caused by the mixing of elements with an equal atomic percent, which can be explained below. The configurational entropy can be calculated by:

$$
\Delta S_{\operatorname{mix}}^{\mathrm{conf}}=-R \sum_{i=1}^{n} x_{i} \ln \left(x_{i}\right)
$$

where $R$ is the ideal gas constant, and $x_{i}$ is the molar fraction concentration of the $i$ th element. For equimolar alloys, this equation reduces to:

$$
\Delta S_{\text {mix }}^{\text {conf }}=R \ln (n)
$$

where $n$ is the number of elements. The higher the $n$, the larger the mixed entropy. According to the Gibbs-free energy:

$$
\Delta G=\Delta H-T \Delta S
$$

where $\Delta H$ is the total enthalpy change relative to a standard state, and $\Delta S$ is the total entropy change. In a sharp contrast to traditional alloys, the inherent high configurational entropy $\left(\Delta S_{\text {mix }}^{\text {conf }}\right)$ of mixing elements in HEAs enhances the formation of solid-solution phases, and suppresses the formation of compounds, especially at high temperatures. Therefore, such a high entropy effect at greater temperatures would homogenize the microstructure, and remove the elemental segregations such as Al-rich, $\mathrm{Cu}$-rich, and/or Cr-rich regions, thus improving the corrosion resistance. For example, in the $\mathrm{CoCrCu}_{0.5} \mathrm{FeNi} \mathrm{HEA}$, after the heat treatment at $1100-1350{ }^{\circ} \mathrm{C}$ for $24 \mathrm{~h}$, the $\mathrm{Cu}$-rich phase was successfully dissolved into the FCC matrix, which resulted in better corrosion properties [56]. However, the heat-treatment temperature should be reasonably selected as sometimes the effect can be contrary to what is desired. The heat treatment of $\mathrm{Al}_{0.5} \mathrm{CoCrFeNi}$ [57] and $\mathrm{CoCrCu}{ }_{0.5} \mathrm{FeNi}$ [56] at 350-900 ${ }^{\circ} \mathrm{C}$ fostered the formation of Al-rich, $\mathrm{Cu}$-rich, and/or $\mathrm{Cr}$-rich phases, leading to the degradation of corrosion resistance in a $3.5 \mathrm{wt} \% \mathrm{NaCl}$ solution. In these cases, the heat treatments should be processed under the guidance of phase-formation rules [58] or thermodynamic-phase diagrams [59] to avoid the formation of undesired phases, thereby reaching the expected corrosion-resistance improvement.

\subsection{Comparison between HEAs and Conventional Alloys}

A detailed comparison of the corrosion behavior between HEAs and conventional corrosionresistant alloys in salt water $(3.5 \mathrm{wt} \% \mathrm{NaCl})$ and acid $\left(0.5 \mathrm{M} \mathrm{H}_{2} \mathrm{SO}_{4}\right)$ is demonstrated in Figures 4 and 5, respectively. Figure 4 shows the comparison of $E_{\text {pit }}$, the parameter which can represent the resistance to pitting corrosion, and $i_{\text {corr, }}$ which is relevant to the corrosion rate as indicated in 
Equation (1), obtained through polarization tests in the $3.5 \mathrm{wt} \% \mathrm{NaCl}$ solution at room temperature. The results were compared with those of some conventional alloys, including stainless steels, $\mathrm{Al}$ alloys, Ti alloys, $\mathrm{Cu}$ alloys, and $\mathrm{Ni}$ alloys [60-66]. The HEAs are located in the lower right part of the figure. The pitting potentials of HEAs are much higher than those of $\mathrm{Al}$ alloys, $\mathrm{Cu}$ alloys, and some Ti alloys, and are comparable with those of stainless steels and Ni alloys, representing their outstanding resistance to localized corrosion, which is the primary failure mode of alloys in the $\mathrm{Cl}^{-}$-containing solution. The corrosion-current densities of HEAs are much lower than $\mathrm{Cu}$ alloys and some Ti alloys, which suggest a relatively lower corrosion rate. Overall, the localized and general corrosion-resistant properties of HEAs are comparable or even superior to those of conventional corrosion-resistant alloys in the $3.5 \mathrm{wt} \% \mathrm{NaCl}$ solution.

As for the comparison of corrosion behavior in $0.5 \mathrm{M} \mathrm{H}_{2} \mathrm{SO}_{4}$, Figure 5 shows the comparison of the $E_{\text {corr }}$ and $i_{\text {corr }}$, which represent the general corrosion resistance. The higher value of $E_{\text {corr }}$ stands for a more noble state of the alloys. Compared with steels, Ti alloys, $\mathrm{Cu}$ alloys, and Ni alloys [67-72], the lower right location of the HEAs in Figure 5 demonstrates the novel corrosion behavior of HEAs in acid. Moreover, as discussed in Sections 2.2 and 2.3, the synthesis of HEA coatings and adequate heat-treatment processes could further improve the corrosion resistance. Thus, it is believed that under the guidance of alloying-effect rules and processing-method optimization, HEAs are good candidates as corrosion-resistant structural or coating alloys in various aqueous environments.

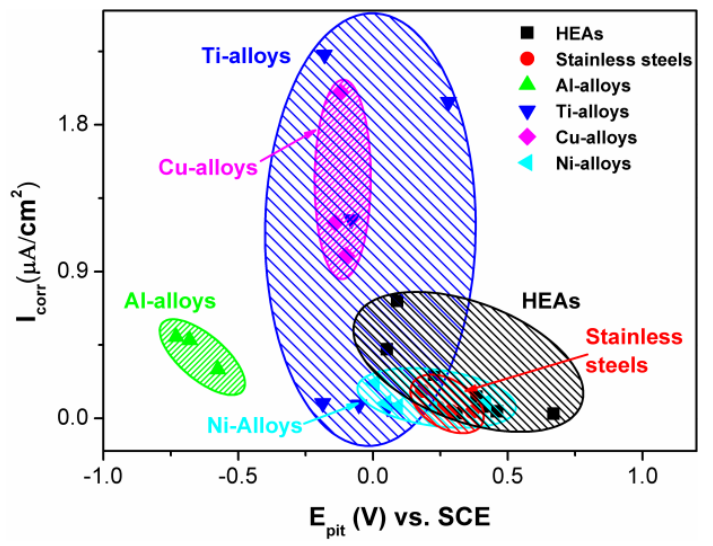

Figure 4. A comparison of the corrosion current density $\left(i_{\text {corr }}\right)$ and pitting potential $\left(E_{\text {pit }}\right)$ between HEAs and other materials in the $3.5 \mathrm{wt} \% \mathrm{NaCl}$ solution at room temperature.

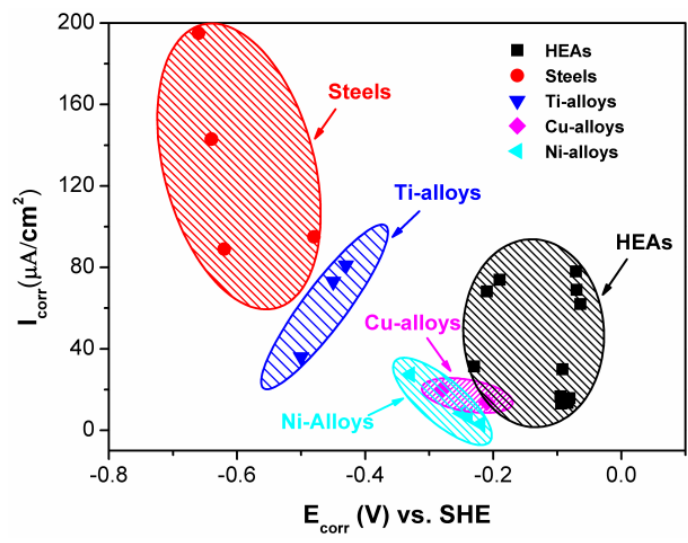

Figure 5. A comparison of the corrosion current density $\left(i_{\text {corr }}\right)$ and corrosion potential $\left(E_{\text {corr }}\right)$ between HEAs and conventional alloys in the $0.5 \mathrm{M} \mathrm{H}_{2} \mathrm{SO}_{4}$ solution at room temperature. 


\section{Discussion}

The effect of environments, elemental additions, and processing routes on the corrosion-resistant property of HEA bulk materials and HEA coatings have been summarized in this article. The recent investigation of the corrosion behavior of HEAs mainly focused on (1) the observation of the corroded surface; (2) electrochemical testing, including potentiodynamic-polarization, cyclic-polarization, and EIS experiments; and (3) the characterization of the passive film by XPS. The results of the recent studies indicated that the corrosion behavior is highly dependent on the surface passive films, which could provide protection for the underlying alloys from dissolution.

In salt water, the presence of detrimental $\mathrm{Cl}^{-}$anions would destroy the passive layer by penetrating through the oxide film at some weak points (where the passive films are relatively loose). Therefore, the common corrosion mode in the $\mathrm{Cl}^{-}$containing solutions is pitting corrosion. Successful native passive films can form if the ingredients for passivation (alloying elements) are present in high enough concentrations. The uniform distribution of passivation elements, such as $\mathrm{Cr}$, could lead to the formation of the homogeneous protective oxide film and decrease the probability of pit formation. However, the additions of $\mathrm{Al}$ and/or $\mathrm{Cu}$ firstly lead to the microstructure transformation, which leads to the elemental segregation, and secondly decrease the amount of the $\mathrm{Cr}$ content. Therefore, the formations of less protective and non-uniform passive films decrease the corrosion resistance. The anodic treatment, addition of Mo, and addition of the inhibitors could either improve the protection of passive films or resist the adsorption/penetration of the $\mathrm{Cl}^{-}$anion, thus improving the corrosion resistance. In acid, the high concentration of $\mathrm{H}^{+}$influences the properties of the oxide films, thus affecting the corrosion behavior. The additions of $\mathrm{Al}, \mathrm{Cu}, \mathrm{Mo}$, and $\mathrm{B}$ could increase the degree of elemental segregation. The presence of $\mathrm{Cr}$-depleted and $\mathrm{Cr}$-rich areas leads to the formation of the galvanic cell, and, therefore, impacts the corrosion resistance. Moreover, the passive film with a higher $\mathrm{Al}$ content tends to be more porous.

The HEA coatings synthesized by laser cladding, electro-spark deposition, and magnetron sputtering showed superior corrosion resistance. The relatively simple and fine microstructure and the decreased ingredient segregation, which are attributed to the rapid cooling process and high entropy effect, reduced the accelerated corrosion effect caused by the formation of the galvanic cell. Therefore, the corrosion resistance properties of HEA coatings are better than of the cast alloys with the same compositions. Besides coatings, heat treatment is another way to improve the homogenization of microstructures and compositions. The high-entropy effect at greater temperatures would homogenize the microstructure, and remove the elemental segregation such as the Al-rich, Cu-rich, and/or Cr-rich regions, thus improving the corrosion resistance. However, the heat treatment temperature should be reasonably selected under the guidance of phase-formation rules or thermodynamic-phase diagrams, in order to avoid the formation of undesired phases.

The present review makes a comparison of general and local corrosion resistance between HEAs and conventional alloys. The relatively higher pitting corrosion and lower corrosion-current density demonstrate greater corrosion resistance of HEAs in both salt water and acid, indicating that HEAs are good candidates as corrosion-resistant alloys in various aqueous environments.

As discussed above, HEAs have great potential in corrosion-resistant applications. The previous studies indicate that the single-phase HEAs without elemental segregations possess the best corrosion resistant properties. However, like the CoCrFeNi HEA, the strength and hardness of single-phase alloys might be too low to meet the requirements in applications. Moreover, the cost of HEAs, which have comparable corrosion resistance, is usually higher than that of the conventional alloys. Those factors might stop HEAs from being used to replace current materials. To solve the above-mentioned problems, suggestions are included in the following section to direct the future work in this field.

\section{Suggested Future Work}

The investigation on the corrosion behavior of HEAs is aimed at designing highly-corrosionresistant HEAs. Therefore, in order to grasp the rules of alloying, processing, and environmental effects, 
and to gain an in-depth, fundamental understanding of the corrosion behavior of HEAs, and realize the usages of HEAs for corrosion-resistant applications, future investigations are suggested below:

1. For the aspect of the comprehensive characterization of corrosion behavior, high-resolution observation of the oxide film formation during the electro-corrosion test should be carried out. The features of HEAs are the disordered chemical environment and the usually formed nanoscale participates due to the slow diffusion rate of the elements. However, the current research results mainly provide microscale characterization and cannot explain the basic reason behind why HEAs possess novel corrosion-resistant properties. Thus, the high-resolution investigation, including the ex-situ and in-situ transmission electron microscopy (TEM) study of passive films, nanoscale atomic-force microscopy (AFM)/scanning transmission electron microscopy (STEM) observations, and depth-profile studies of passive films that have nano-thicknesses, could provide an atomistic understanding and is a prerequisite for the control of electrochemical surface processes.

2. Since the homogenization of microstructures and elemental distributions can remarkably improve the corrosion resistance, a certain heat treatment and rapid cooling rate during the formation of coatings could improve the corrosion behavior through the attainment of uniform microstructures. However, guidance for the development of these uniform microstructures is absent. Therefore, both equilibrium and non-equilibrium thermodynamics calculations to predict the phase formation/transformation need to be conducted.

3. Through coatings, firstly, the problem of the higher cost of HEAs could be resolved. Secondly, the satisfactory corrosion-resistant property could be retained with the addition of strengthening elements such as Al. Thus, insufficient mechanical properties that stop the HEAs from being used could be solved. Therefore, the study of how to synthesize high-quality HEA coatings is one of the major research directions for exploring the application of HEAs as corrosion-resistant materials. The effect of processing parameters and alloying should be taken into consideration.

4. HEAs exhibit promising potential for applications in industry. However, the synergistic effects of service environments have not been widely considered, including the effects of residual stress, stress-corrosion cracking, and corrosion fatigue. Those investigations are indispensable for real-world applications.

\section{Conclusions}

This article reviews the investigation during the last decade on the corrosion behavior of HEAs. The effects of environments, elemental additions, and processing routes on the corrosion-resistant properties of bulk HEAs and HEA coatings have been summarized and discussed.

1. The surface passive films, which could provide the protection for the underlying alloys from dissolution, are of importance to the corrosion behavior. The additions of $\mathrm{Al}, \mathrm{Cu}, \mathrm{Mo}$, and/or $\mathrm{B}$ increase the degree of elemental segregation, and lead to the formation of non-uniform passive films, which could induce galvanic corrosion or the localized break down of the passive films. Therefore, these elemental additions decrease the corrosion resistance in salt water and/or acid. In salt water, the anodic treatment, addition of Mo, and inclusion of the inhibitors could either improve the protection of the passive film or resist the penetration of $\mathrm{Cl}^{-}$anions, thus improving the corrosion resistance.

2. Some HEAs possess novel corrosion behavior in high-temperature, high-pressure water environments, thus indicating that HEAs have the capacity of being applied in supercritical service environments.

3. The HEA coatings synthesized by laser cladding, electro-spark deposition, and magnetron sputtering showed superior corrosion resistance. Attributed to the rapid-cooling process and high-entropy effect, the microstructure and elemental distribution of the coatings are more homogeneous than the bulk materials. The reduced formation of weak points in the passive film and galvanic cell improve the corrosion resistance. 
4. During the heat treatment of HEAs at elevated temperatures, the high-entropy effect would homogenize the microstructures and compositions, and remove the elemental segregations, therefore improving the corrosion resistance. However, the heat treatment temperature should be selected suitably under the guidance of phase formation rules to avoid the formation of undesired participates.

5. The comparison of the corrosion behavior between HEAs and conventional alloys indicates that HEAs are good candidates as corrosion-resistant alloys in various aqueous environments. However, to gain an in-depth understanding of corrosion behavior, the high resolution observations of corrosion processes are suggested for future work. Moreover, the phase-formation rules under both equilibrium and non-equilibrium conditions need to be developed to guide the heat treatment and coating processes.

Acknowledgments: Y.S. is grateful to the China Scholarship Council for the financial support during her visit to The University of Tennessee. B.Y. is very grateful for the support from the "863" Program of China under Nos. 2008AA031702 and 2012AA03A507. P.K.L. would like to acknowledge the support of the Department of Energy (DOE), Office of Fossil Energy, National Energy Technology Laboratory (DE-FE-0024054 and DE-FE-0011194), with V. Cedro, R. Dunst, and J. Mullen as program managers. P.K.L. very much appreciates the support of the U.S. Army Research Office project (W911NF-13-1-0438) with the program manager, D.M. Stepp. P.K.L. thanks the support from the National Science Foundation (DMR-1611180) with the program director, D. Farkas. P.K.L. would like to thank QuesTek Innovations LLC under Award No. DE-SC0013220 with J. Saal as the program manager.

Conflicts of Interest: The authors declare no conflict of interest.

\section{References}

1. Koch, G.H.; Brongers, M.P.; Thompson, N.G.; Virmani, Y.P.; Payer, J.H. Corrosion Cost and Preventive Strategies in the United States; U.S. Federal Highway Administration: Washington, DC, USA, 2001.

2. Cramer, S.D.; Covino, B.S., Jr. ASM Handbook, Volume 13A-Corrosion: Fundamentals, Testing, and Protection; ASM International: Novelty, OH, USA, 2003.

3. Nilsson, J.O.; Wilson, A. Influence of isothermal phase transformations on toughness and pitting corrosion of super duplex stainless steel SAF 2507. Mater. Sci. Technol. 1993, 9, 545-554. [CrossRef]

4. Cvijović, Z.; Radenković, G. Microstructure and pitting corrosion resistance of annealed duplex stainless steel. Corros. Sci. 2006, 48, 3887-3906. [CrossRef]

5. Wang, Y.Q.; Han, J.; Wu, H.C.; Yang, B.; Wang, X.T. Effect of sigma phase precipitation on the mechanical and wear properties of Z3CN20.09M cast duplex stainless steel. Nucl. Eng. Des. 2013, 259, 1-7. [CrossRef]

6. Yeh, J.W.; Chen, S.K.; Lin, S.J.; Gan, J.Y.; Chin, T.S.; Shun, T.T.; Tsau, C.H.; Chang, S.Y. Nanostructured high-entropy alloys with multiple principal elements: Novel alloy design concepts and outcomes. Adv. Eng. Mater. 2004, 6, 299-303. [CrossRef]

7. Cantor, B.; Chang, I.T.H.; Knight, P.; Vincent, A.J.B. Microstructural development in equiatomic multicomponent alloys. Mater. Sci. Eng. 2004, 375-377, 213-218. [CrossRef]

8. Zhang, Y.; Zuo, T.T.; Tang, Z.; Gao, M.C.; Dahmen, K.A.; Liaw, P.K.; Lu, Z.P. Microstructures and properties of high-entropy alloys. Prog. Mater. Sci. 2014, 61, 1-93. [CrossRef]

9. Zhang, Y.; Zhou, Y.J.; Lin, J.P.; Chen, G.L.; Liaw, P.K. Solid-solution phase formation rules for multi-component alloys. Adv. Eng. Mater. 2008, 10, 534-538. [CrossRef]

10. Senkov, O.N.; Wilks, G.B.; Miracle, D.B.; Chuang, C.P.; Liaw, P.K. Refractory high-entropy alloys. Intermetallics 2010, 18, 1758-1765. [CrossRef]

11. Gao, M.C. Chapter 11: Design of high-entropy alloys. In High-Entropy Alloys: Fundamentals and Applications; Gao, M.C., Yeh, J.W., Liaw, P.K., Zhang, Y., Eds.; Springer: Cham, Switzerland, 2016.

12. Gao, M.C.; Zhang, B.; Guo, S.M.; Qiao, J.W.; Hawk, J.A. High-entropy alloys in hexagonal close-packed structure. Metall. Mater. Trans. A 2016, 47, 3322-3332. [CrossRef]

13. Feuerbacher, M.; Heidelmann, M.; Thomas, C. Hexagonal high-entropy alloys. Mater. Res. Lett. 2015, 3, 1-6. [CrossRef]

14. Youssef, K.M.; Zaddach, A.J.; Niu, C.; Irving, D.L.; Koch, C.C. A novel low-density, high-hardness, high-entropy alloy with close-packed single-phase nanocrystalline structures. Mater. Res. Lett. 2015, 3, 95-99. [CrossRef] 
15. Diao, H.; Santodonato, L.J.; Tang, Z.; Egami, T.; Liaw, P.K. Local structures of high-entropy alloys (HEAs) on atomic scales: An overview. JOM 2015, 67, 2321-2325. [CrossRef]

16. Chen, Y.Y.; Duval, T.; Hung, U.D.; Yeh, J.W.; Shih, H.C. Microstructure and electrochemical properties of high entropy alloys-A comparison with type-304 stainless steel. Corros. Sci. 2005, 47, 2257-2279. [CrossRef]

17. Chen, Y.Y.; Hong, U.T.; Shih, H.C.; Yeh, J.W.; Duval, T. Electrochemical kinetics of the high entropy alloys in aqueous environments-A comparison with type 304 stainless steel. Corros. Sci. 2005, 47, 2679-2699. [CrossRef]

18. Tang, Z.; Huang, L.; He, W.; Liaw, P. Alloying and processing effects on the aqueous corrosion behavior of high-entropy alloys. Entropy 2014, 16, 895-911. [CrossRef]

19. Qiu, Y.; Gibson, M.A.; Fraser, H.L.; Birbilis, N. Corrosion characteristics of high entropy alloys (heas). J. Mater. Sci. Technol. 2015, 31, 1235-1243. [CrossRef]

20. Liu, Y.-X.; Cheng, C.-Q.; Shang, J.-L.; Wang, R.; Li, P.; Zhao, J. Oxidation behavior of high-entropy alloys $\mathrm{Al}_{x} \mathrm{CoCrFeNi}(x=0.15,0.4)$ in supercritical water and comparison with HR3C steel. Trans. Nonferr. Met. Soc. China 2015, 25, 1341-1351. [CrossRef]

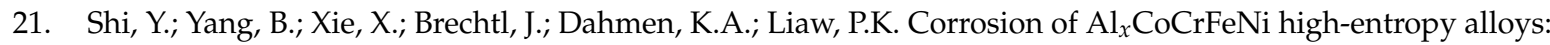
Al-content and potential scan-rate dependent pittng behavior. Corros. Sci. under review.

22. Senkov, O.N.; Senkova, S.V.; Woodward, C. Effect of aluminum on the microstructure and properties of two refractory high-entropy alloys. Acta Mater. 2014, 68, 214-228. [CrossRef]

23. Li, Z.; Pradeep, K.G.; Deng, Y.; Raabe, D.; Tasan, C.C. Metastable high-entropy dual-phase alloys overcome the strength-ductility trade-off. Nature 2016, 534, 227-230. [CrossRef] [PubMed]

24. Hemphill, M.A.; Yuan, T.; Wang, G.Y.; Yeh, J.W.; Tsai, C.W.; Chuang, A.; Liaw, P.K. Fatigue behavior of $\mathrm{Al}_{0.5} \mathrm{CoCrCuFeNi}$ high entropy alloys. Acta Mater. 2012, 60, 5723-5734. [CrossRef]

25. Tang, Z.; Yuan, T.; Tsai, C.-W.; Yeh, J.-W.; Lundin, C.D.; Liaw, P.K. Fatigue behavior of a wrought $\mathrm{Al}_{0.5} \mathrm{CoCrCuFeNi}$ two-phase high-entropy alloy. Acta Mater. 2015, 99, 247-258. [CrossRef]

26. Seifi, M.; Li, D.; Yong, Z.; Liaw, P.K.; Lewandowski, J.J. Fracture toughness and fatigue crack growth behavior of as-cast high-entropy alloys. JOM 2015, 67, 2288-2295. [CrossRef]

27. Gludovatz, B.; Hohenwarter, A.; Catoor, D.; Chang, E.H.; George, E.P.; Ritchie, R.O. A fracture-resistant high-entropy alloy for cryogenic applications. Science 2014, 345, 1153-1158. [CrossRef] [PubMed]

28. Zhang, Z.; Mao, M.M.; Wang, J.; Gludovatz, B.; Zhang, Z.; Mao, S.X.; George, E.P.; Yu, Q.; Ritchie, R.O. Nanoscale origins of the damage tolerance of the high-entropy alloy CrMnFeCoNi. Nat. Commun. 2015, 6, 10143. [CrossRef] [PubMed]

29. Santodonato, L.J.; Zhang, Y.; Feygenson, M.; Parish, C.M.; Gao, M.C.; Weber, R.J.; Neuefeind, J.C.; Tang, Z.; Liaw, P.K. Deviation from high-entropy configurations in the atomic distributions of a multi-principal-element alloy. Nat. Commun. 2015, 6, 5964. [CrossRef] [PubMed]

30. Ye, X.; Ma, M.; Liu, W.; Li, L.; Zhong, M.; Liu, Y.; Wu, Q. Synthesis and characterization of high-entropy alloy FeCoNiCuCr by laser cladding. Adv. Mater. Sci. Eng. 2011, 2011, 1-7. [CrossRef]

31. Zhang, H.; Pan, Y.; He, Y.; Jiao, H. Microstructure and properties of $6 \mathrm{FeNiCoSiCrAlTi} \mathrm{high-entropy} \mathrm{alloy}$ coating prepared by laser cladding. Appl. Surf. Sci. 2011, 257, 2259-2263. [CrossRef]

32. Cheng, J.B.; Liang, X.B.; Xu, B.S. Effect of $\mathrm{Nb}$ addition on the structure and mechanical behaviors of CoCrCuFeNi high-entropy alloy coatings. Surf. Coat. Technol. 2014, 240, 184-190. [CrossRef]

33. Shon, Y.; Joshi, S.S.; Katakam, S.; Shanker Rajamure, R.; Dahotre, N.B. Laser additive synthesis of high entropy alloy coating on aluminum: Corrosion behavior. Mater. Lett. 2015, 142, 122-125. [CrossRef]

34. Li, Q.H.; Yue, T.M.; Guo, Z.N.; Lin, X. Microstructure and corrosion properties of AlCoCrFeNi high entropy alloy coatings deposited on AISI 1045 steel by the electrospark process. Metall. Mater. Trans. A 2012, 44, 1767-1778. [CrossRef]

35. An, Z.; Jia, H.; Wu, Y.; Rack, P.D.; Patchen, A.D.; Liu, Y.; Ren, Y.; Li, N.; Liaw, P.K. Solid-solution CrCoCuFeNi high-entropy alloy thin films synthesized by sputter deposition. Mater. Res. Lett. 2015, 3, 203-209. [CrossRef]

36. Dou, D.; Li, X.C.; Zheng, Z.Y.; Li, J.C. Coatings of FeAlCoCuNiV high entropy alloy. Surf. Eng. 2016, 32, 766-770. [CrossRef]

37. Li, X.; Zheng, Z.; Dou, D.; Li, J. Microstructure and properties of coating of FeAlCuCrCoMn high entropy alloy deposited by direct current magnetron sputtering. Mater. Res. 2016, 19, 802-806. [CrossRef] 
38. Zhang, S.; Wu, C.L.; Zhang, C.H.; Guan, M.; Tan, J.Z. Laser surface alloying of FeCoCrAlNi high-entropy alloy on 304 stainless steel to enhance corrosion and cavitation erosion resistance. Opt. Laser Technol. 2016, 84, 23-31. [CrossRef]

39. Xiang, C.; Fu, H.; Wang, J.; Han, E.-H.; Zhang, Z. Corrosion behavior of several high-entropy alloys in high temperature high pressurewater. J. Chin. Soc. Corros. Prot. 2016, 36, 108-112.

40. Presuel-Moreno, F.; Jakab, M.A.; Tailleart, N.; Goldman, M.; Scully, J.R. Corrosion-resistant metallic coatings. Mater. Today 2008, 11, 14-23. [CrossRef]

41. Lee, C.P.; Chang, C.C.; Chen, Y.Y.; Yeh, J.W.; Shih, H.C. Effect of the aluminium content of $\mathrm{Al}_{x} \mathrm{CrFe}_{1.5} \mathrm{MnNi}_{0.5}$ high-entropy alloys on the corrosion behaviour in aqueous environments. Corros. Sci. 2008, 50, 2053-2060. [CrossRef]

42. Kao, Y.-F.; Lee, T.-D.; Chen, S.-K.; Chang, Y.-S. Electrochemical passive properties of alxcocrfeni $(x=0,0.25$, $0.50,1.00)$ alloys in sulfuric acids. Corros. Sci. 2010, 52, 1026-1034. [CrossRef]

43. Lee, C.P.; Chen, Y.Y.; Hsu, C.Y.; Yeh, J.W.; Shih, H.C. Enhancing pitting corrosion resistance of $\mathrm{Al}_{x} \mathrm{CrFe}_{1.5} \mathrm{MnNi}_{0.5}$ high-entropy alloys by anodic treatment in sulfuric acid. Thin Solid Films 2008, 517, 1301-1305. [CrossRef]

44. Hsu, Y.-J.; Chiang, W.-C.; Wu, J.-K. Corrosion behavior of FeCoNiCrCu $\mathrm{F}_{x}$ high-entropy alloys in 3.5\% sodium chloride solution. Mater. Chem. Phys. 2005, 92, 112-117. [CrossRef]

45. Chou, Y.L.; Yeh, J.W.; Shih, H.C. The effect of molybdenum on the corrosion behaviour of the high-entropy alloys $\mathrm{Co}_{1.5} \mathrm{CrFeNi}_{1.5} \mathrm{Ti}_{0.5} \mathrm{Mo}_{x}$ in aqueous environments. Corrosi. Sci. 2010, 52, 2571-2581. [CrossRef]

46. Chou, Y.L.; Yeh, J.W.; Shih, H.C. Effect of inhibitors on the critical pitting temperature of the high-entropy alloy $\mathrm{Co}_{1.5} \mathrm{CrFeNi}_{1.5} \mathrm{Ti}_{0.5} \mathrm{Mo}_{0.1}$. J. Electrochem. Soc. 2011, 158, C246-C251. [CrossRef]

47. Chou, Y.L.; Wang, Y.C.; Yeh, J.W.; Shih, H.C. Pitting corrosion of the high-entropy alloy $\mathrm{Co}_{1.5} \mathrm{CrFeNi}_{1.5} \mathrm{Ti}_{0.5} \mathrm{Mo}_{0.1}$ in chloride-containing sulphate solutions. Corros. Sci. 2010, 52, 3481-3491. [CrossRef]

48. Ren, B.; Liu, Z.X.; Li, D.M.; Shi, L.; Cai, B.; Wang, M.X. Corrosion behavior of CuCrFeNiMn high entropy alloy system in $1 \mathrm{M}$ sulfuric acid solution. Mater. Corros. 2011, 828-834. [CrossRef]

49. Pourbaix, M. Atlas of Electrochemical Equilibria in Aqueous Solutions; NACE International: Houston, TX, USA, 1974.

50. Lee, C.P.; Chen, Y.Y.; Hsu, C.Y.; Yeh, J.W.; Shih, H.C. The effect of boron on the corrosion resistance of the high entropy alloys $\mathrm{Al}_{0.5} \mathrm{CoCrCuFeNiB}_{x}$. J. Electrochem. Soc. 2007, 154, C424-C430. [CrossRef]

51. Zhang, H.; Pan, Y.; He, Y.-Z. Synthesis and characterization of FeCoNiCrCu high-entropy alloy coating by laser cladding. Mater. Des. 2011, 32, 1910-1915. [CrossRef]

52. Ye, X.; Ma, M.; Cao, Y.; Liu, W.; Ye, X.; Gu, Y. The property research on high-entropy alloy alxfeconicucr coating by laser cladding. Phys. Procedia 2011, 12, 303-312. [CrossRef]

53. Qiu, X.W.; Zhang, Y.P.; Liu, C.G. Effect of Ti content on structure and properties of $\mathrm{Al}_{2} \mathrm{CrFeNiCoCuTi}_{x}$ high-entropy alloy coatings. J. Alloys Compd. 2014, 585, 282-286. [CrossRef]

54. Qiu, X.-W.; Liu, C.-G. Microstructure and properties of $\mathrm{Al}_{2} \mathrm{CrFeCoCuTiNi}_{x}$ high-entropy alloys prepared by laser cladding. J. Alloys Compd. 2013, 553, 216-220. [CrossRef]

55. Qiu, X.-W.; Zhang, Y.-P.; He, L.; Liu, C.-G. Microstructure and corrosion resistance of AlCrFeCuCo high entropy alloy. J. Alloys Compd. 2013, 549, 195-199. [CrossRef]

56. Lin, C.-M.; Tsai, H.-L.; Bor, H.-Y. Effect of aging treatment on microstructure and properties of high-entropy $\mathrm{Cu}_{0.5} \mathrm{CoCrFeNi}$ alloy. Intermetallics 2010, 18, 1244-1250. [CrossRef]

57. Lin, C.-M.; Tsai, H.-L. Evolution of microstructure, hardness, and corrosion properties of high-entropy $\mathrm{Al}_{0.5} \mathrm{CoCrFeNi}$ alloy. Intermetallics 2011, 19, 288-294. [CrossRef]

58. Feng, R.; Gao, M.; Lee, C.; Mathes, M.; Zuo, T.; Chen, S.; Hawk, J.; Zhang, Y.; Liaw, P. Design of light-weight high-entropy alloys. Entropy 2016, 18, 333. [CrossRef]

59. Zhang, C.; Zhang, F.; Diao, H.; Gao, M.C.; Tang, Z.; Poplawsky, J.D.; Liaw, P.K. Understanding phase stability of Al-Co-Cr-Fe-Ni high entropy alloys. Mater. Des. 2016, 109, 425-433. [CrossRef]

60. Kwok, C.T.; Cheng, F.T.; Man, H.C. Synergistic effect of cavitation erosion and corrosion of various engineering alloys in 3.5\% NaCl solution. Mater. Sci. Eng. A 2000, 290, 145-154. [CrossRef]

61. Delgado-Alvarado, C.; Sundaram, P.A. A study of the corrosion behavior of gamma titanium aluminide in 3.5 wt \% nacl solution and seawater. Corros. Sci. 2007, 49, 3732-3741. [CrossRef] 
62. Al-Fozan, S.A.; Malik, A.U. Effect of seawater level on corrosion behavior of different alloys. Desalination 2008, 228, 61-67. [CrossRef]

63. Peng, X.; Zhang, Y.; Zhao, J.; Wang, F. Electrochemical corrosion performance in $3.5 \% \mathrm{NaCl}$ of the electrodeposited Nanocrystalline $\mathrm{Ni}$ films with and without dispersions of $\mathrm{Cr}$ nanoparticles. Electrochim. Acta 2006, 51, 4922-4927. [CrossRef]

64. Ezuber, H.; El-Houd, A.; El-Shawesh, F. A study on the corrosion behavior of aluminum alloys in seawater. Mater. Des. 2008, 29, 801-805. [CrossRef]

65. Wang, Y.Q.; Li, N.; Yang, B. Effect of ferrite on pitting corrosion of $\mathrm{Fe}_{20} \mathrm{Cr}_{9} \mathrm{Ni}$ cast austenite stainless steel for nuclear power plant pipe. Corros. Eng. Sci. Technol. 2014, 50, 330-337. [CrossRef]

66. Sarkar, P.P.; Kumar, P.; Manna, M.K.; Chakraborti, P.C. Microstructural influence on the electrochemical corrosion behaviour of dual-phase steels in 3.5\% NaCl solution. Mater. Lett. 2005, 59, 2488-2491. [CrossRef]

67. McCafferty, E. Validation of corrosion rates measured by the TaFel extrapolation method. Corros. Sci. 2005, 47, 3202-3215. [CrossRef]

68. Hong, J.H.; Lee, S.H.; Kim, J.G.; Yoon, J.B. Corrosion behaviour of copper containing low alloy steels in sulphuric acid. Corros. Sci. 2012, 54, 174-182. [CrossRef]

69. Park, S.-A.; Lee, S.-H.; Kim, J.-G. Effect of chromium on the corrosion behavior of low alloy steel in sulfuric acid. Met. Mater. Int. 2012, 18, 975-987. [CrossRef]

70. Baik, S.-Y. The study of corrosion behavior for solution and aging heat treated Ti alloy. J. Korean Soc. Mar. Environ. Saf. 2016, 22, 138-144. [CrossRef]

71. Lu, G.; Zangari, G. Corrosion resistance of ternary Ni-p based alloys in sulfuric acid solutions. Electrochim. Acta 2002, 47, 2969-2979. [CrossRef]

72. Moretti, G.; Guidi, F. Tryptophan as copper corrosion inhibitor in $0.5 \mathrm{~m}$ aerated sulfuric acid. Corros. Sci. 2002, 44, 1995-2011. [CrossRef]

(C) 2017 by the authors; licensee MDPI, Basel, Switzerland. This article is an open access article distributed under the terms and conditions of the Creative Commons Attribution (CC BY) license (http:/ / creativecommons.org/licenses/by/4.0/). 